\title{
An Investigation into the Benefits of the Intercultural Approach to EFL Learning and Teaching: A Case Study of Taif University, KSA
}

\author{
Amir H. Abdalla \\ College of Education \& Science, Taif University, KSA
}

\begin{abstract}
The purpose of this study is to investigate the potential benefits of using the intercultural approach to teaching English as a foreign language in the preparatory -year programme (male branch), Taif University, Kingdom of Saudi Arabia. The intercultural approach is considered a viable means of foreign language education that seeks to address issues of culture in foreign language learning and teaching and how best to address them. Hence, this study intends to explore the attitudes of first year EFL Taif university students to the potential benefits of the intercultural approach to EFL. A sample of 200 EFL students participated in the study. Participants' views on the topic of the study are collected via a questionnaire the researcher designed and administered to the participants. In addition, the views of $50 \mathrm{EFL}$ instructors teaching in the preparatory programme were gathered by a questionnaire regarding the topic researched. Descriptive statistics were used to analyse the collected data.
\end{abstract}

Index Terms - awareness, approach, competence, intercultural, mixed-ability, target language

\section{INTRODUCTION}

In today's EFL teaching-learning situation, it goes without saying that teaching English as a foreign language is not only related to the teaching of linguistic facts of the target language such as phonology, morphology, vocabulary and syntax. The contemporary models of communicative competence demonstrated that learning a foreign language brings together the vital components of cultural knowledge together with awareness, favourable attitudes to the target language and its culture and the motivation to learn them. To put it differently, the learning of English as a foreign language requires, in addition to the skills and mechanics of the language, a knowledge of some socio-cultural aspects of the target language.

Dobrovol'skij \& Piirainen (2006), Colson (2008) and Williams (2010) claim that language is inseparable from its culture. Therefore, teaching any language will inevitably involve teaching its culture. Only through understanding the culture of the target language will a language learner be able to function properly in the language s/he is learning.

\section{A. Literature Review}

The intercultural approach to EFL is underlined by the multi-faceted word 'culture' which everybody inherently knows what it refers to and what it includes. Peterson (2004) envisages two levels of culture as is shown in the diagram below:

TABLE 1

(PETERSON'S LEVELS OF CULTURE)

\begin{tabular}{|l|l|l|}
\cline { 2 - 3 } \multicolumn{1}{c|}{} & $\begin{array}{l}\text { Big 'C' culture } \\
\text { Classic or grand themes }\end{array}$ & $\begin{array}{l}\text { Small 'c' culture } \\
\text { Minor or common themes }\end{array}$ \\
\hline $\begin{array}{l}\text { Invisible Culture } \\
\text { "Bottom of the iceberg” }\end{array}$ & $\begin{array}{l}\text { EXAMPLES: } \\
\text { Core values attitudes or beliefs, society's norms, } \\
\text { legal foundations, history, cognitive processes, }\end{array}$ & $\begin{array}{l}\text { EXAMPLES: } \\
\text { Popular issues, opinion, viewpoint, preferences } \\
\text { or tastes, certain knowledge (trivia fact) }\end{array}$ \\
\hline $\begin{array}{l}\text { Visible Culture } \\
\text { "Tip of the iceberg” }\end{array}$ & $\begin{array}{l}\text { EXAMPLES: } \\
\text { Architecture, geography, classical literature, } \\
\text { president or political figure, classical music }\end{array}$ & $\begin{array}{l}\text { EXAMPLES: } \\
\text { Gestures, body posture, use of space, clothing, } \\
\text { style, food, hobbies, music artwork }\end{array}$ \\
\hline
\end{tabular}

It can be said that the diagram encompasses the external world of reality, a speech community and its distinct ways (i.e. culture) man-made things, and a language which is the means of bringing together all of the parts mentioned in the diagram. People use language to express facts, notions, feelings, likes and dislikes, name things, relate to one another, etc. Therefore, language, communication and culture go hand in hand in every human society.

In the context of EFL, learners are expected to achieve a degree of intercultural communication and understanding in relation to the target language and its culture. It is the duty of EFL teachers to make abundantly clear to learners that success in learning the English language requires not only knowing the words, spelling, grammar and syntactic structures of the language but also a working knowledge of the cultural aspects and meanings native speakers attach to 
their language. Tomalin \& Stempleski (1993) believed that injecting a culture component into the EFL learning materials helps learners to understand the following:

1. Culture influences the behaviours of speakers of all human languages.

2. Social variables such as age, gender, class, and place of residence affect the way individuals use their native language.

3. Certain situations require specific reactions depending on the native language.

4. Language units such as words and phrases have cultural elemenst.

5. Culture sharpens the ability to make generalizations about how speakers of the target language use their language.

6. Culture develops the necessary skills to understand how speakers of the target language organize their language.

7. Culture stimulates student's cognitive skills as to how to get along with speakers of other languages.

Likewise, Méndez García (2005: 208-210) sums up the importance of the presence of intercultural communication elements in the EFL syllabus for the following reasons:

- Enhancing students' knowledge of human languages.

- Acquainting them with the key behavioral patterns of the target societies.

- Promoting attitudes of respect and tolerance.

- Encouraging reflection upon one's own culture.

- Developing real intercultural communication in an intercultural world.

Of course, ELF learners, who are usually mature learners, come to the task of learning English having already acquired their L1 along with its socio-cultural modes of communication. Moreover, it is a known fact that EFL learners are usually monolingual and they learn English while living in their own country (Krieger 2005). On becoming EFL learners, students are faced with questions like these:

1. How to be competent using English in situations where culture determines language use?

2. Can they make use of their L1 culture in dealing with sociolinguistic situations that they are not familiar with in the FL?

3. Does comparing L1 culture to FL culture always work?

4. How rewarding is knowledge of the FL culture to EFL learners who are eager to succeed in learning the language?

5. What are the best ways to learn the cultural aspects of the FL in the context of EFL?

Developing adequate cultural awareness and understanding in the EFL context can be a tall order particularly in situations where the FL culture and L1 culture are quite distinct. Furthermore, it has to be born in mind that EFL learners do not have much access to the target language culture and therefore their ability to become culturally competent in the FL is very much reduced particularly if the materials and syllabuses they are using are not tailored to enhancing their socio-cultural competence in the FL. What was found to be working in building EFL learners' cultural awareness and understanding is time and adequate exposure. According to Tanaka (2006:37) EFL learners go through the following stages towards achieving cultural competence in target language:

First, Cross-Cultural Knowledge which is a prerequisite for cross-cultural understanding. The inability to appreciate other cultures often stems from the absence of knowledge about them. Respect and appreciation of a culture will be achieved if people are made familiar with it.

Second, with adequate Cross-Cultural Knowledge, people will develop Cross-Cultural Awareness i.e. they will show understanding and appreciation, which may be accompanied by changes in behaviour and attitudes towards the culture.

Third, proper cross-cultural awareness will naturally produce cross-cultural sensitivity which relates to the ability to read the situations, contexts and behaviors that are linked to culture. A suitable response indicates that not every time people bring their own culturally- determined interpretations of the situation and/or behaviour.

Fourth, only through the possession of adequate Cross-Cultural Knowledge, Cross- Cultural Awareness, and CrossCultural Sensitivity will learners achieve Cross-Cultural Competence which can be regarded as the final stage of cross cultural understanding and signifies the learners' ability to work effectively across cultures.

As this study seeks to answer the main question of why the intercultural approach to EFL is needed in today's world of foreign language learning and teaching can best be seen in the learner competencies list produced by the Council of Europe (2001). This list outlines five key competencies as follows:

1. Digital competence

This is about learners' ability to confidently and critically use information society technology for the purposes of work, leisure and communication.

2. Learning to learn

This competence is concerned with learners' readiness to withstand the difficulties to be encountered in learning and to organize their learning relying on the most effective learning strategies.

3. Communal competences

These involve personal, interpersonal and intercultural competences and cover all forms of behaviour that enable the individual to effectively take part in the social and working life in their communities.

4. Sense of initiative and entrepreneurship competence

This competence is concerned with the ability put ideas into actions. It includes creativity, innovation and risk-taking together with the ability to plan and control projects so as realize the stated aims 
5. Cultural awareness and expression

This competence is said to help learners acquire the knowledge they need to learn in given any field of human knowledge. Thus, cultural awareness and expression are needed for the creative expression of ideas, experiences and emotions.

It is worth mentioning that this study focuses mainly on the last competence according to the European Council learner competencies list outlined above. According to Kiet Ho (2009:63), Intercultural language learning is the stance on language teaching and learning that emphasizes the interdependence of language and culture and the importance of intercultural understanding as a goal of language education. It is increasingly being promoted as a way to develop learners' ability to negotiate meanings in different languages which will ultimately prepare them to live in a multicultural world.

Judging by both EFL learners' and teachers' experience, it can be said that students' linguistic competence alone is sometimes insufficient for them to express their ideas and thoughts in the FL. Therefore, they need to develop their intercultural communicative competence together with their linguistic competence which is vital for effective crosscultural communication. It is the conviction of the researcher that when EFL learners are exposed to the language via the intercultural approach, they get the benefit of developing their critical cultural awareness together with the skills to understanding and successfully interacting with people from other cultures, thus, they become interculturally as well as linguistically competent EFL learners.

In addition, EFL learners who learn the language through the intercultural approach are found to have the following characteristics:

1. Their behaviour:

- Flexibility

- intercultural approach

2. Their attitudes and/or affective capacities:

- Acknowledgement of the identities of others

- Respect for otherness

- Tolerance for ambiguity

- Empathy

3. Their Cognitive capacities:

- Knowledge

- Knowledge discovery

- Interpreting and relating

- Critical cultural awareness

(Byram, 2006: 22-26)

The communicative competence model of Canale and Swain (1980) is based on the understanding of the relationship between language and culture. Linguistic, discourse, sociolinguistic, and strategic competence each incorporates features of culture, and the development of these abilities is connected with the development of cultural awareness.

"The exquisite connection between the culture that is lived and the language that is spoken can only be realized by those who possess a knowledge of both" (1999: 47). In this respect bringing language and culture together for the sake of communication means more than using the four language skills. The role of culture here is seen as a facilitator to communicate with and understand speakers from different backgrounds.

\section{Principles for Culture Teaching}

Byram and Morgan (1994) stress that learners need to engage actively in the interpretations of the world and compare and contrast the shared meanings of both their own and foreign cultures. They should have access to routine and conscious knowledge held by the members of the foreign culture so that they can adjust to routine behaviors and allusive communication. They should also learn about institutions and artifacts like literature, film, history and political institutions in order to further analyze the values and meanings of foreign culture. Byram and Morgan also suggest the so-called "spiral curriculum" in which learners repeatedly encounter certain information and progress from a superficial acquisition of information to a more complex analysis.

Similarly, Kramsch (1993) emphasizes the importance of learner involvement into culture instruction by highlighting what she calls "new ways of looking at the teaching of language and culture, which include establishing a sphere of interculturality, teaching culture as an interpersonal process, teaching culture as difference, and crossing disciplinary boundaries.

Teaching culture as a component of foreign language learning has long been the concern of many scholars and researchers for decades, thus, different approaches to culture teaching have been put forward. Some of these approaches focus only on the culture of the country whose language is learned and is considered inadequate nowadays because it does not consider learners' understanding of their own culture. Other approaches seek to bring together the learner's native language culture and the target culture (Saluveer, 2004).

Risager (1998:243-252) describes four approaches to the teaching culture:

1. The intercultural approach

2. The multicultural approach 
3. The transcultural approach

4. The foreign cultural approach

According to these four approaches, the intercultural and multicultural approaches include a considerable element of comparison. The transcultural approach presupposes foreign language as an international language. The foreign cultural approach only focuses on the target culture where the language is spoken.

\section{B. Aims of the Study}

The main aim of this study is to gain some insights as to whether the intercultural approach to learning and teaching English as a foreign language (EFL) offers substantial benefits to EFL university students in Saudi Arabia.

By conducting the study, the researcher would like to achieve the following objectives:

1. To study the effect of culture in EFL learning-teaching context.

2. To find out how the home culture of EFL learners affects their perception of the FL culture together with the English language itself.

3. To explore how the interaction between FL culture and the L1 culture affects positively and /or negatively EFL learners' attitudes towards learning the English language.

4. To raise EFL learners' awareness to the role culture plays in learning the English language.

\section{Limitation of the Study}

This study is limited to a group of beginning EFL learners $(n=200)$ taking a two-semester intensive English programme as part of the requirements to pursue BA study at Taif university, KSA during the academic year 2014-2015.

\section{METHODOLOGY}

\section{A. Questions of the Study}

This study was conducted to provide answers to the following questions:

1. What effect(s) can culture have on EFL learning?

2. How likely are EFL learners going to benefit from the interplay of their L1 culture with the FL culture?

3. To what extent are EFL learners' attitudes to the English language shaped by the way they draw comparisons between the two cultures involved?

4. Can it be true that only highly motivated EFL learners are more likely to appreciate the role cross-cultural understanding plays in EFL learning?

5. Compared to other approaches to EFL learning and teaching, how effective is the intercultural approach with Saudi EFL learners?

\section{B. Participants of the Study}

The sample of the study $(n=200)$ was randomly drawn from first-year EFL male students at Taif University, College of Education and Science in Khurma. 50 EFL instructors have also accepted to take part in the study by filling a questionnaire regarding their views on the benefits of the intercultural approach to EFL learning and teaching.

TABLE 2

\begin{tabular}{|l|l|l|}
\multicolumn{2}{c|}{ (PARTICIPANTS OF THE STUDY) } \\
\cline { 2 - 3 } \multicolumn{1}{c|}{} & EFL students & EFL instructors \\
\hline Study participants & $\mathrm{n}=200$ & $\mathrm{n}=50$ \\
\hline
\end{tabular}

\section{Instruments of Data Collection}

A two-section questionnaire was administered to the sample of the ( $n=200)$. In section (A) of the questionnaire, participants were asked to react to 20-culture related items taken from the different units of their textbooks. Responses are to be indicated using a scale ranging from very similar to very different the items are in their native culture and the target language culture (see appendix A).Section (B) of the questionnaire asks students to state whether they think that knowing about the formerly mentioned 20-culture related items in section (A) very useful, somewhat useful or not useful at all.

As for the 50 EFL instructors who participated in the study, the researcher requested them to fill a questionnaire of ten items asking their views as to what they think the intercultural approach to EFL can help their students to improve their competency and proficiency in the target language. The instructors' questionnaire uses a 3-point scale of agree, neutral and disagree (see appendix B).

\section{Statistical Analyses}

The data collected via the students' and instructors' questionnaires was statistically treated using measures of descriptive statistics especially the mean and the standard deviation. The first part of the analysis handles the data generated by the students' responses (n 200) to sections (A) and (B) of the questionnaire. Teachers' views (n 50) on the 
intercultural approach to teaching English as a foreign language are tabulated and analysed in the second part of the analysis.

TABLE 3.1 A

(STUDENTS' RESPONSES TO SECTION A OF THE QUESTIONNAIRE)

\begin{tabular}{|c|c|c|c|c|c|c|c|c|c|}
\hline & \multirow[t]{2}{*}{ Item } & \multicolumn{2}{|c|}{ Very similar } & \multicolumn{2}{|c|}{ Somewhat similar } & \multicolumn{2}{|c|}{ Somewhat different } & \multicolumn{2}{|c|}{ Very different } \\
\hline & & $\mathrm{Nr}$ & $\%$ & $\mathrm{Nr}$ & $\%$ & $\mathrm{Nr}$ & $\%$ & $\mathrm{Nr}$ & $\%$ \\
\hline 1 & Foods and drinks & 0 & 0 & 5 & 2.5 & 25 & 12.5 & 170 & 85 \\
\hline 2 & Family structure and relations & 10 & 5 & 20 & 10 & 80 & 40 & 90 & 45 \\
\hline 3 & Men's wear & 5 & 2.5 & 20 & 10 & 25 & 12.5 & 150 & 75 \\
\hline 4 & Women's wear & 0 & 0 & 0 & 0 & 20 & 10 & 180 & 90 \\
\hline 5 & Use of photos & 10 & 5 & 40 & 20 & 50 & 25 & 100 & 50 \\
\hline 6 & Daily routines & 10 & 5 & 40 & 20 & 70 & 35 & 80 & 40 \\
\hline 7 & Leisure time & 70 & 35 & 60 & 30 & 45 & 22.5 & 25 & 12.5 \\
\hline 8 & Eating with family and friends & 20 & 10 & 30 & 15 & 30 & 15 & 120 & 60 \\
\hline 9 & Giving personal information & 40 & 20 & 80 & 40 & 50 & 25 & 30 & 15 \\
\hline 10 & Men and women in public places & 0 & 0 & 0 & 0 & 12 & 6 & 188 & 94 \\
\hline
\end{tabular}

$*$ Total number of respondents $=200$

TABLE 3.1B

(STUDENTS' RESPONSES TO SECTION A OF THE QUESTIONNAIRE)

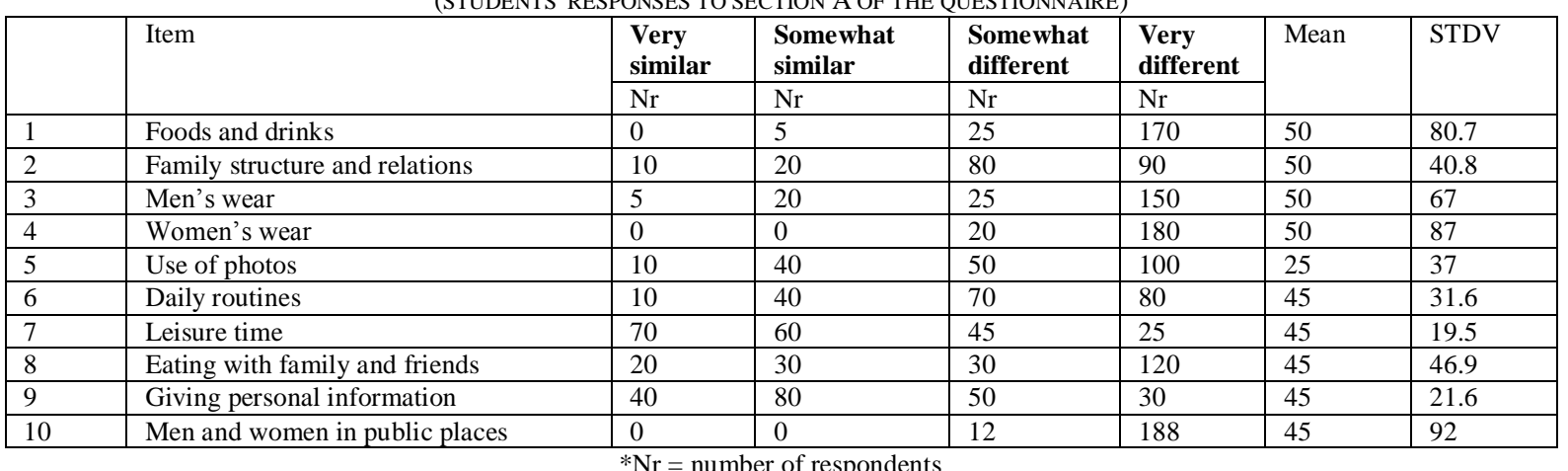

$*$ Total number of respondents $=200$

Tables 3.1a and 3.1b show respondents' answers to items one to ten of sections (A) and (B) of the questionnaire. According to table 3.1a respondents indicated their answers following a 4-point scale ranging from 'very similar' to 'very different' relating to ten items corresponding to the main topics of each unit in student textbooks English 1, 2 and 3. High among the items which respondents rated as very different between their L1 culture and the target language culture are: men mingling with women in public places 94\% (the mean 45 and the StdDev 92); women's wear 90\% (the mean 50 and the StdDev 87); foods and drinks 85\%(the mean 50 and the StdDev 80.7)and men's wear 75\% (the mean 50 and the StdDev 67).Interestingly, $70 \%$ of respondents rated the item leisure time' as very similar in both L1 culture and the target language culture. $60 \%$ of respondents regarded the item 'eating with family and friends' as very different in the two cultures compared. As for the item 'family structure and relations', respondents were almost split in the middle: $45 \%$ considered them as very different whereas $40 \%$ believed them to be only somewhat different.

TABLE 3.1C

(STUDENTS' RESPONSES TO SECTION A OF THE QUESTIONNAIRE)

\begin{tabular}{|c|c|c|c|c|c|c|c|c|c|}
\hline & \multirow[t]{2}{*}{ Item } & \multicolumn{2}{|c|}{ Very similar } & \multicolumn{2}{|c|}{ Somewhat similar } & \multicolumn{2}{|c|}{ Somewhat different } & \multicolumn{2}{|c|}{ Very different } \\
\hline & & $\mathrm{Nr}$ & $\%$ & $\mathrm{Nr}$ & $\%$ & $\mathrm{Nr}$ & $\%$ & $\mathrm{Nr}$ & $\%$ \\
\hline 11 & Use of formal and informal names & 20 & 10 & 30 & 15 & 50 & 25 & 100 & 50 \\
\hline 12 & Having a pet/ pets & 15 & 7.5 & 40 & 20 & 55 & 27.5 & 90 & 45 \\
\hline 13 & Celebrating important events & 25 & 12.5 & 50 & 25 & 60 & 30 & 65 & 32.5 \\
\hline 14 & Spending holidays & 50 & 25 & 80 & 40 & 50 & 25 & 20 & 10 \\
\hline 15 & Respecting old people & 15 & 7.5 & 35 & 17.5 & 60 & 30 & 90 & 45 \\
\hline 16 & Talking/ writing about one's own life experiences & 10 & 5 & 40 & 20 & 50 & 25 & 100 & 50 \\
\hline 17 & Greeting/meeting other people & 20 & 10 & 30 & 15 & 70 & 35 & 80 & 40 \\
\hline 18 & Visiting family members and friends & 20 & 10 & 50 & 25 & 60 & 30 & 70 & 35 \\
\hline 19 & Sensitivity to gender issues & 5 & 2.5 & 25 & 12.5 & 70 & 35 & 100 & 50 \\
\hline 20 & Planning for one's own future & 30 & 15 & 50 & 25 & 50 & 25 & 70 & 35 \\
\hline
\end{tabular}

Tables 3.1c and 3.1d show respondents' answers to the remaining statements of section (A) of the questionnaire. Half of the students who filled the questionnaire (n 200) stated that they find that the use of formal and informal names in L1 culture and the target language culture very different (i.e. 50\%). May be this is due to the tradition in Arabic culture 
whereby fathers and mothers are usually given the name of their elder child preceded by 'Abu' means father of or 'Um' means mother of. For example, if a couple had a first child named Ahmed, the father will be called Abu-Ahmed (father of Ahmed) and the mother will be called Um-Ahmed (mother of Ahmed). This tradition is generally upheld whether the elder child is a son or a daughter.

According to $45 \%$ the respondents, having a pet/pets is very different in their culture compared to the culture of native English-speakers. Apart from using animals such as falcons and trained hunter dogs, Saudi city and town dwellers are rarely seen with cats and dogs as adults see the practice as more to do with children. Respondents' reaction to the statement about celebrating important events in the two cultures drew diverse responses ranged from somewhat similar $(25 \%)$ to somewhat different $(30 \%)$ to very different $(32 \%)$. Regarding how the speakers of the two languages studied spend their holidays, the majority of respondents (i.e. 130 out of 200) have indicated that the two cultures are either somewhat similar $(40 \%)$ or very similar $(25 \%)$.

When it comes to the question of respecting old people, $45 \%$ of the respondents agreed that the L1 culture and the target language culture differ on the issue but not remarkably (the mean 45 and the StdDev 37). As to whether visiting family members and friends is similar or different in the two cultures compared, $35 \%$ of respondents stated that they are very different, $30 \%$ regarded the two cultures as somewhat different and $25 \%$ agreed that the two cultures are somewhat similar concerning the issue of visiting family members and friends.

According to respondents, the question of sensitivity to gender issues revealed that the answers tended to skew more to the somewhat different-very different sides of the scale. 170 of the respondents (n 200) tended to regard the L1 culture as either somewhat different or very different from the target language culture relating to sensitivity to gender issues. When respondents were asked about how do they culturally regard talking/ writing about their own life experiences, 50\% (the mean 45 and the StdDev 29) did state that their L1 culture is very different from the target language culture on vis-à-vis the question. Concerning the issue of planning for their own future, respondents' answers scattered almost evenly along the three points of the scale of somewhat similar to somewhat different to very different; i.e. $25 \%, 25 \%$ and $35 \%$ respectively.

TABLE 3.1D

(STUDENTS' RESPONSES TO SECTION A OF THE QUESTIONNAIRE)

\begin{tabular}{|c|c|c|c|c|c|c|c|}
\hline & Item & $\begin{array}{l}\text { Very } \\
\text { similar } \\
\end{array}$ & $\begin{array}{l}\text { Somewhat } \\
\text { similar }\end{array}$ & $\begin{array}{l}\text { Somewhat } \\
\text { different }\end{array}$ & $\begin{array}{l}\text { Very } \\
\text { different }\end{array}$ & Mean & STDV \\
\hline & & $\mathrm{Nr}$ & $\mathrm{Nr}$ & $\mathrm{Nr}$ & $\mathrm{Nr}$ & 45 & 35.6 \\
\hline 11 & Use of formal and informal names & 20 & 30 & 50 & 100 & 45 & 31 \\
\hline 12 & Having a pet/ pets & 15 & 40 & 55 & 90 & 45 & 17.8 \\
\hline 13 & Celebrating important events & 25 & 50 & 60 & 65 & 45 & 24.5 \\
\hline 14 & Spending holidays & 50 & 80 & 50 & 20 & 45 & 32 \\
\hline 15 & Respecting old people & 15 & 35 & 60 & 90 & 45 & 37 \\
\hline 16 & Talking/ writing about one's own life experiences & 10 & 40 & 50 & 100 & 45 & 29 \\
\hline 17 & Greeting/meeting other people & 20 & 30 & 70 & 80 & 45 & 21.6 \\
\hline 18 & Visiting family members and friends & 20 & 50 & 60 & 70 & 45 & 43 \\
\hline 19 & Sensitivity to gender issues & 5 & 25 & 70 & 100 & 45 & 16 \\
\hline 20 & Planning for one's own future & 30 & 50 & 50 & 70 & 45 & 35.6 \\
\hline
\end{tabular}

$* \mathrm{Nr}=$ number of respondents

$*$ Total number of respondents $=200$

In section (B) of the questionnaire, the students who participated in the study (n 200) were asked to indicate whether they find knowing about twenty of the target language culture-related items helpful in learning English. Responses were indicated on the basis of a three-point scale of very useful, somewhat useful and not useful.

TABLE 3.2A

(STUDENTS' RESPONSES TO SECTION B OF THE QUESTIONNAIRE)

\begin{tabular}{|c|c|c|c|c|c|c|c|c|c|}
\hline & \multirow[t]{2}{*}{ Item } & \multicolumn{2}{|c|}{ Very useful } & \multicolumn{2}{|c|}{ Somewhat useful } & \multicolumn{2}{|c|}{ Not useful } & \multirow[t]{2}{*}{ Mean } & \multirow[t]{2}{*}{ STDV } \\
\hline & & $\mathrm{Nr}$ & $\%$ & $\mathrm{Nr}$ & $\%$ & $\mathrm{Nr}$ & $\%$ & & \\
\hline 1 & Foods and drinks & 85 & 42.5 & 90 & 45 & 25 & 12.5 & 66.7 & 36 \\
\hline 2 & Family structure and relations & 70 & 35 & 120 & 60 & 10 & 5 & 66.7 & 55 \\
\hline 3 & Men's wear & 70 & 35 & 110 & 55 & 20 & 10 & 66.7 & 45 \\
\hline 4 & Women's wear & 60 & 30 & 100 & 50 & 40 & 20 & 66.7 & 30.6 \\
\hline 5 & Use of photos & 95 & 47.5 & 80 & 40 & 25 & 12.5 & 66.7 & 36.9 \\
\hline 6 & Daily routines & 65 & 32.5 & 120 & 60 & 15 & 7.5 & 66.7 & 52.5 \\
\hline 7 & Leisure time & 60 & 30 & 100 & 50 & 40 & 20 & 66.7 & 30.6 \\
\hline 8 & Eating with family and friends & 130 & 65 & 50 & 25 & 20 & 10 & 66.7 & 56.9 \\
\hline 9 & Giving personal information & 88 & 44 & 90 & 45 & 22 & 11 & 66.7 & 38.7 \\
\hline 10 & Men and women in public places & 70 & 35 & 100 & 50 & 30 & 15 & 66.7 & 35 \\
\hline
\end{tabular}

$*$ Total number of respondents $=200$

According to the data in table 3.2a, the vast majority of respondents (i.e. 175 out of 200) did state that they find knowing about foods and drinks in the target language culture very useful in learning English. Regarding family structure and relations in the two cultures compared, $60 \%$ the students agreed that knowledge of the issue is somewhat 
useful in learning the target language (the mean 66.7 and the StdDev 55). However, 55.5 of the participants pointed out that they consider topics in their EFL syllabus about visiting family members and friends very useful (see statement number eighteen, table 3.2b). Topics connected to men's and women's wears modestly feature on the English syllabus respondents study. When asked to state whether they find these topics useful to learn English, 55\% indicated that they find topics about men's wear somewhat useful compared to $50 \%$ for women's wear. Given that the participants are all young male EFL students, topics related to women's wears are generally believed to be interesting and motivating for them to engage in classroom activities and discussions.

130 of the respondents (n 200) pointed out that they consider topics about eating with family and friends very useful in learning English. This may help them develop their English vocabulary pertaining to names and types of foods, table manners and etiquette in the target language culture compared to their L1 culture. Adult men and women who are not legally married or part of the immediate/ nuclear family are strictly forbidden to mingle in public places in the kingdom of Saudi Arabia. 170\% of the respondents ticked the very useful and somewhat useful scales of the questionnaire (35\% and $50 \%$ respectively) concerning the issue of men and women socializing in public places.

It is not part of this study's aims or scope to ascertain whether the twenty items given in the questionnaire used to collect data for the study (and which match with titles of different units of students' English 1, 2 and 3 textbooks) are made according to any needs analysis survey. However, items like the ones in the questionnaire of the study are commonly found in EFL syllabi and widely accepted to motivate and enthuse learners in matters of communication and interaction.

The figures in table $3.2 \mathrm{~b}$ show that the majority of respondents regarded knowing about how native English speakers respect their elders, how they spend their holidays and how they meet with /greet others as very useful $(55 \%, 50 \%$ and $50 \%$ respectively). Concerning matters to do with sensitivity to gender issues, $50 \%$ of the students who took part in the study stated that they find topics in their EFL syllabus tackling gender issues as only somewhat useful.

Given that all of the respondents are very young Saudi EFL first-year university students, 130 participants (n 200) indicated that they find topics in the target language culture dealing with planning for one's own future as very useful(the mean 66.7 and the StdDev 60).

TABLE 3.2B

(STUDENTS' RESPONSES TO SECTION B OF THE QUESTIONNAIRE)

\begin{tabular}{|c|c|c|c|c|c|c|c|c|c|}
\hline & \multirow[t]{2}{*}{ Item } & \multicolumn{2}{|c|}{ Very useful } & \multicolumn{2}{|c|}{ Somewhat useful } & \multicolumn{2}{|c|}{ Not useful } & \multirow[t]{2}{*}{ Mean } & \multirow[t]{2}{*}{ STDV } \\
\hline & & $\mathrm{Nr}$ & $\%$ & $\mathrm{Nr}$ & $\%$ & $\mathrm{Nr}$ & $\%$ & & \\
\hline 11 & Use of formal and informal names & 60 & 30 & 90 & 45 & 50 & 25 & 66.7 & 20.8 \\
\hline 12 & Having a pet/ pets & 50 & 25 & 89 & 44.5 & 61 & 30.5 & 66.7 & 20 \\
\hline 13 & Celebrating important events & 95 & 47.5 & 88 & 44 & 17 & 8.5 & 66.7 & 43 \\
\hline 14 & Spending holidays & 100 & 50 & 70 & 35 & 30 & 15 & 66.7 & 35 \\
\hline 15 & Respecting old people & 110 & 55 & 80 & 40 & 10 & 5 & 66.7 & 51 \\
\hline 16 & Talking/ writing about one's life experience & 95 & 47.5 & 80 & 40 & 25 & 12.5 & 66.7 & 36.9 \\
\hline 17 & Greeting/meeting other people & 100 & 50 & 88 & 44 & 12 & 6 & 66.7 & 47.7 \\
\hline 18 & Visiting family members and friends & 111 & 55.5 & 80 & 40 & 9 & 4.5 & 66.7 & 52 \\
\hline 19 & Sensitivity to gender issues & 77 & 38.5 & 100 & 50 & 23 & 11.5 & 66.7 & 39.5 \\
\hline 20 & Planning for one's own future & 130 & 65 & 60 & 30 & 10 & 5 & 66.7 & 60 \\
\hline
\end{tabular}

Having dealt with the students' responses to sections (A) and (B) of the questionnaire administered to collect data on the benefits of the intercultural approach to EFL learning and teaching, we move on now to the analysis of the data relating to teachers' views on the issue. A ten-item questionnaire was filled by $50 \mathrm{EFL}$ instructors teaching in the preparatory-year intensive English programme of Taif University, KSA. The questionnaire uses a three-point scale of agree, neutral and disagree. 
TABLE 3.3

(INSTRUCTORS' RESPONSES TO THE QUESTIONNAIRE)

\begin{tabular}{|c|c|c|c|c|c|c|c|c|c|}
\hline \multicolumn{2}{|c|}{ Statement } & $\begin{array}{l}\text { AG } \\
\text { Res }\end{array}$ & $\%$ & $\begin{array}{l}\text { NU } \\
\text { Res }\end{array}$ & $\%$ & $\begin{array}{l}\text { DA } \\
\text { Res }\end{array}$ & $\%$ & $\mathrm{M}$ & STDV \\
\hline 1 & $\begin{array}{l}\text { Intercultural learning activities help raise EFL learners' } \\
\text { awareness. }\end{array}$ & 35 & $70 \%$ & 10 & $20 \%$ & 5 & $10 \%$ & 12 & 16 \\
\hline 2 & $\begin{array}{l}\text { Intercultural learning activities make EFL learners good } \\
\text { speakers of English }\end{array}$ & 25 & $50 \%$ & 15 & $30 \%$ & 10 & $20 \%$ & 5.5 & 7.6 \\
\hline 3 & $\begin{array}{l}\text { Discussions based on intercultural topics help learners to } \\
\text { generate ideas for writing tasks }\end{array}$ & 40 & $80 \%$ & 10 & $20 \%$ & 0 & $0 \%$ & 6 & 20.8 \\
\hline 4 & $\begin{array}{l}\text { Intercultural learning techniques help EFL learners to } \\
\text { become proficient readers in English }\end{array}$ & 30 & $60 \%$ & 15 & $30 \%$ & 5 & $10 \%$ & 4 & 12.5 \\
\hline 5 & $\begin{array}{l}\text { Intercultural learning activities improve EFL learners' } \\
\text { pronunciation }\end{array}$ & 20 & $40 \%$ & 20 & $40 \%$ & 10 & $20 \%$ & 3.5 & 5.7 \\
\hline 6 & $\begin{array}{l}\text { The Intercultural approach to EFL encourage shy and } \\
\text { introverted learners }\end{array}$ & 25 & $50 \%$ & 15 & $30 \%$ & 10 & 20 & 3 & 7.6 \\
\hline 7 & $\begin{array}{l}\text { Even mixed-ability EFL classrooms can be taught } \\
\text { English via intercultural activities }\end{array}$ & 35 & $70 \%$ & 5 & $10 \%$ & 10 & $20 \%$ & 2.8 & 16 \\
\hline 8 & $\begin{array}{l}\text { Intercultural learning activities may help motivate EFL } \\
\text { learners to learn more languages }\end{array}$ & 45 & $90 \%$ & 5 & $10 \%$ & 0 & $0 \%$ & 2.6 & 24.6 \\
\hline 9 & $\begin{array}{l}\text { Intercultural learning activities prepare EFL to Live and } \\
\text { work abroad }\end{array}$ & 30 & $60 \%$ & 15 & $30 \%$ & 5 & $10 \%$ & 2.4 & 12.5 \\
\hline $\begin{array}{l}1 \\
0\end{array}$ & $\begin{array}{l}\text { Intercultural learning materials make EFL learners more } \\
\text { sensitive to politically-correct language. }\end{array}$ & 25 & $50 \%$ & 20 & $40 \%$ & 5 & $10 \%$ & 2 & 10 \\
\hline
\end{tabular}

According to table $3.3,70 \%$ of the instructors (n 50) who responded to the teachers' questionnaire (see appendix ii) agreed that intercultural learning activities help raise EFL learners' awareness to learning the target language. As to whether intercultural learning activities make EFL learners good speakers of English, 50\% of the respondents did agree with the statement whereas 30\% expressed uncertainty regarding the statement and $20 \%$ disagreed with it (the mean 5.5 and the StdDev 7.6).

40 of the EFL instructors who participated in the study (n 50) agreed that discussions based on intercultural topics help EFL learners generate ideas needed for classroom writing tasks. In relation to the reading skill, $60 \%$ of the instructors who filled the questionnaire believed that intercultural learning techniques help EFL learners to become proficient readers in English. Interestingly, respondents' answers to the question whether intercultural learning activities improve EFL learners' pronunciation generated these responses: $40 \%$ agreed, $40 \%$ were neutral and $20 \%$ disagreed (the mean 3.5 and the StdDev 5.7).

Does the intercultural approach to EFL encourage shy and introverted learners? The figures in table 3.3 show that $50 \%$ of the instructors surveyed said yes to the question; $30 \%$ chose neither to be on the yes side nor on the no side of the question and $20 \%$ answered the question in the negative.

It goes without saying that all EFL instructors (the researcher is included) must have experienced working with mixed-ability classrooms in one way or another. Statement number seven of the questionnaire asked respondents whether they agree or disagree that the mixed-ability EFL classroom can be taught the target language via intercultural activities. $70 \%$ of the respondents agreed and $20 \%$ disagreed on the suitability of intercultural activities for mixedability EFL classrooms. In connection with the issue of motivation and EFL learners, 45 out of 50 of the instructors surveyed did agree that intercultural learning activities may help motivate EFL learners to learn more foreign languages.

Can intercultural learning activities prepare EFL learners to live and work in environments different from the ones they were born in? According to the views of $60 \%$ of the instructors who took part in the study, the answer is yes intercultural learning activities can prepare EFL learners to live and work abroad compared to $30 \%$ who said they were not sure whether they can. Statement number ten of the questionnaire asked instructors whether they agree that EFL learners who are exposed to the target language through intercultural learning materials are more sensitive to politicallycorrect language. $50 \%$ of the instructors indicated their agreement with the statement, while $40 \%$ said they were not certain about the issue.

\section{RESULTS OF THE STUDY}

Based on the data analysis of the two instruments of data collection this study employed (i.e. students' and instructors questionnaires), a number of results were arrived at. Data was analysed using several measures of descriptive statistics, specifically, percentage tally, the mean and the standard deviation. In connection with the results and findings, a couple of caveats must be stated: first, these results and findings are of significance only in relation to the group of EFL students (n 200) who participated in the study. Second, the views expressed by the EFL instructors who took part in the study (n 50) may not necessarily be representative of EFL teachers in other parts of the world.

1. Although the majority of the students participated in the study indicated that the they find most of the questionnaire items (e.g. foods and drinks, men and women wear, men and women in public places) very different in 
the L1 culture vis-à-vis the target language culture, yet they agreed that it is important for them as students of English to know these culture-specific differences.

2. Among the items respondents agreed are somewhat similar between the two cultures studied are the following: daily routines, giving personal information, celebrating important events and spending holidays.

3. The only item on the questionnaire rated as similar in both the L1 culture and the target language culture is the way leisure time is spent.

4. According to the teachers' questionnaire, the majority of the EFL instructors surveyed agreed that the intercultural approach to EFL has a lot of potential for EFL students regarding most of the language skills. In addition, the approach can also motivate students and raise their awareness to features of the target language and may prepare them to live and work in cultures different from the ones they were born in.

5. The intercultural approach to EFL instruction can be used with mixed-ability classrooms and it may also help shy and introverted learners to overcome their fears working with other class mates.

6. Half of the instructors who returned the questionnaire (n 50) did agree that intercultural learning materials may make EFL students more sensitive to using and understanding politically-correct language.

As to the extent to which the results and findings of the study may have provided some answers to the questions of the study the following can be established:

With regard to questions one and three of the study, the former asks about the effect(s) culture can have on EFL learning and teaching whereas the latter asks whether EFL learners' attitudes to the English language may have been shaped by the way they draw comparisons between the two cultures involved, the figures in tables 3.1a, 3.1b, 3.1c, 3.1d, $3.2 \mathrm{a}$ and $3.2 \mathrm{~b}$ lend a lot of support for saying that culture substantially affects the way EFL learners perceive the task of learning a foreign language. Likewise and given that the study participants are all very young freshmen Saudi university students and they have access to state-of-the-art technologies to connect with the rest of the world, culture comparison must be something they are aware of and interested in.

How likely are EFL learners going to benefit from the interplay of their L1 culture with the FL culture is the second question the study asks. Both of students' and instructors' responses to the questionnaires show that awareness of target language culture by way of comparing it to L1 culture especially during classroom activities, helps a lot in matters to do with motivation, lowering shy students' affective filter and generating ideas for discussions and writing tasks.

Question five of the study asked the EFL instructors who responded to the questionnaire whether they consider the intercultural approach with Saudi EFL learners effective in comparison to other EFL approaches. Instructors' answers to statements number one, three, four, seven, eight and nine of the questionnaire (see table 3.3) indicate that they regard the intercultural approach with Saudi university EFL students effective.

\section{CONCLUSION}

This study was conducted to investigate the potential benefits of the intercultural approach to EFL learning and teaching. 200 first-year Taif University male students and 50 of their instructors teaching at the English language centre's preparatory year two-semester intensive programme took part in the study. The main aim of the study was to gain some insights as to whether the intercultural approach to learning and teaching English as a foreign language offers substantial benefits to EFL university students in Saudi Arabia.

Two instruments of data collection were employed: students' questionnaire and instructors' questionnaire. The data generated was statistically treated using several measures of descriptive statistics. Based on the statistical analysis, a number of results were arrived at which showed that the questions this study was meant to provide answers for may have sufficiently been answered.

\section{APPENDiX A. STUDENTS' QuestionNAIRE}

\section{Section (A)}

Dear student,

According to what you have studied in your textbooks English 1, 2 and 3; comparing your own Arabic culture to the cultures of English-speaking people in the three textbooks, how do you think the following features are similar or different from your own culture? (Tick $\sqrt{ }$ your answer) 


\begin{tabular}{|c|c|c|c|c|c|}
\hline & Feature & Very similar & Somewhat similar & Somewhat different & Very different \\
\hline 1 & Foods and drinks & & & & \\
\hline 2 & Family structure and relations & & & & \\
\hline 3 & Men's wear & & & & \\
\hline 4 & Women's wear & & & & \\
\hline 5 & Use of photos & & & & \\
\hline 6 & Daily routines & & & & \\
\hline 7 & Leisure time & & & & \\
\hline 8 & Eating with family and friends & & & & \\
\hline 9 & Giving personal information & & & & \\
\hline 10 & Men and women in public places & & & & \\
\hline 11 & Use of formal and informal names & & & & \\
\hline 12 & Having a pet/ pets & & & & \\
\hline 13 & Celebrating important events & & & & \\
\hline 14 & Spending holidays & & & & \\
\hline 15 & Respecting old people & & & & \\
\hline 16 & Talking/ writing about one's own life experiences & & & & \\
\hline 17 & Greeting/meeting other people & & & & \\
\hline 18 & Visiting family members and friends & & & & \\
\hline 19 & Sensitivity to gender issues & & & & \\
\hline 20 & Planning for one's own future & & & & \\
\hline
\end{tabular}

\section{Section (B)}

According to what you have studied in your textbooks English 1, 2 and 3; comparing your own Arabic culture to the cultures of the English-speaking people in the three textbooks, which of the following features do you think are useful to know about and which are not? (Tick $\sqrt{ }$ your answer)

\begin{tabular}{|l|l|l|l|l|}
\hline & Feature & Very useful & Somewhat useful & Not useful \\
\hline 1 & Foods and drinks & & & \\
\hline 2 & Family structure and relations & & & \\
\hline 3 & Men's wear & & & \\
\hline 4 & Women's wear & & & \\
\hline 5 & Use of photos & & & \\
\hline 6 & Daily routines & & & \\
\hline 7 & Leisure time & & & \\
\hline 8 & Eating with family and friends & & & \\
\hline 9 & Giving personal information & & & \\
\hline 10 & Men and women in public places & & & \\
\hline 11 & Use of formal and informal names & & & \\
\hline 12 & Having a pet/ pets & & & \\
\hline 13 & Celebrating important events & & & \\
\hline 14 & Spending holidays & & & \\
\hline 15 & Respecting old people & & & \\
\hline 16 & Talking/writing about one's own life experiences & & & \\
\hline 17 & Greeting/meeting other people & & & \\
\hline 18 & Visiting family members and friends & & & \\
\hline 19 & Sensitivity to gender issues & & & \\
\hline 20 & Planning for one's own future & & & \\
\hline
\end{tabular}

Thank you very much for your time

Dr. Amir H. Abdalla

English Dept

May 2015

APPENDIX B. INSTRUCTORS' QUESTIONNAIRE

Dear colleague,

This questionnaire is intended to collect your views regarding the potential benefits of the intercultural approach to EFL learning and teaching at Taif University, KSA.

Please respond to each of the following statements by ticking $(\sqrt{ })$ your choice: 


\begin{tabular}{|c|c|c|c|c|}
\hline & Statement & $\mathbf{A G}$ & NU & DA \\
\hline 1 & Intercultural learning activities help raise EFL learners' awareness to learning the target language. & & & \\
\hline 2 & Intercultural learning activities make EFL learners good speakers of English. & & & \\
\hline 3 & $\begin{array}{l}\text { In relation to classroom writing practices, discussions based on intercultural topics help EFL learners } \\
\text { generate ideas needed for the writing tasks. }\end{array}$ & & & \\
\hline 4 & Intercultural learning techniques help EFL learners to become proficient readers in English. & & & \\
\hline 5 & Intercultural learning activities improve EFL learners pronunciation. & & & \\
\hline 6 & $\begin{array}{l}\text { The Intercultural approach to EFL may encourage shy and introverted learners to overcome their } \\
\text { learning difficulties. }\end{array}$ & & & \\
\hline 7 & Even mixed-ability EFL classrooms can be taught the target language via intercultural activities. & & & \\
\hline 8 & Intercultural learning activities may help motivate EFL learners to learn more foreign languages. & & & \\
\hline 9 & $\begin{array}{l}\text { Intercultural learning activities prepare EFL learners to live and work in environments different from } \\
\text { the ones they were born In. }\end{array}$ & & & \\
\hline 10 & $\begin{array}{l}\text { EFL learners who are exposed to the target language through intercultural learning materials are more } \\
\text { sensitive to politically-correct language. }\end{array}$ & & & \\
\hline
\end{tabular}

I very much appreciate your cooperation and insights

- $\mathrm{AG}=$ Agree

- UD = Undecided

- DA = Disagree

Dr. Amir H. Abdalla

English Dept

May 2015

\section{REFERENCES}

[1] Alptekin, C. (2002). Towards intercultural communicative competence in ELT. ELT Journal 56 (1): 57-64.

[2] Baker, W. (2012). "From Cultural Awareness to Intercultural Awareness: Culture in ELT", ELT Journal, Vol. 66/1: 62-70.

[3] Byram, M. and Morgan, C. (1994). Teaching and learning language and culture. Clevedon: Multilingual Matters.

[4] Byram, M. (2006). Language teaching for intercultural citizenship: the European situation. Paper presented at the NZALT conference, University of Auckland.

[5] Canale, M. \& Swain, M. (1980). Theoretical bases of communicative approaches to second language teaching and testing. Applied Linguistics. 1, 1-47.

[6] Coleman, H. (Ed.) (1996). Society and the language classroom. Cambridge: CUP.

[7] Colson, J.P. (2008). "Cross-linguistic Phraseological studies" in S. Granger, S. and F. Meunier, F. (eds) Phraseology: An Interdisciplinary perspective (pp.191-206). Amsterdam \&Philadelphia:John Benjamin Publishing Company.

[8] Corbett, J. (2003). An Intercultural Approach to English Language Teaching, Multilingual Matters Ltd, Clevedon.

[9] Cortazzi, M., \& Jin, L. (1999). Cultural mirrors: Materials and methods in the EFL classroom. In E. Hinkel (Ed.), Culture in second language teaching and learning (pp. 196-219). Cambridge: Cambridge University Press.

[10] Council of Europe. (2001). Common European framework of reference for languages: Learning, teaching, assessment. Cambridge: Cambridge University Press. Retrieved April 28, 2015 from: www.coe.int/t/dg4/linguistic/Source/ Framework_EN.pdf.

[11] Dobrovol'skij, D. and E. Piirainen. (2006). Cultural knowledge and idioms. International Journal of English Studies, 6 (1), $27-$ 41.

[12] Fantini, A.E. (2000). 'A Central Concern: Developing Intercultural Competence'. SIT Occasional Paper Series, Issue No., 1. 2000. PP 25-42.

[13] Ho, S. T. K. (2009). "Addressing Culture in EFL Classrooms: The Challenge of Shifting from a Traditional to an Intercultural Stance", Electronic Journal of Foreign Language Teaching, No. 1: pp. 63-76, Centre for Language Studies, National University of Singapore, Retrieved March 22,2015, from: http://e-flt.nus.edu.sg/.

[14] Kramsch, C. (1993). Context and culture in language teaching. Oxford: Oxford University press.

[15] Kumaravadivelu, B. (2008). Cultural globalization and language education. New Haven: Yale University Press.

[16] Méndez García, M. C. (2005). International and inter- cultural issues in English teaching textbooks: the case of Spain. Intercultural Education, 16, (1), 57-68.

[17] Pennycook, A. (2007). Global Englishes and transcultural flows. London: Routledge.

[18] Peterson, R.A. (2004). Where the Two Cultures Meet: Popular Culture. The journal of popular culture.11 (2).385-400.

[19] Risager, K. (1998). Language Teaching and the Process of European Integration. In M. Byram and M. Fleming (eds.), Language learning in intercultural perspective. Approaches through drama and ethnography. Cambridge: Cambridge University Press.

[20] Starkey, H. (1991). World studies and foreign language teaching: Converging approaches in textbook writing. In D. Buttjes \& M. Byram (Eds.), Mediating languages and cultures (pp. 209-227). Clevedon: Multilingual Matters.

[21] Tomalin, B. \& Stempleski, S. (1993). Cultural Awareness. Oxford: Oxford University press.

[22] Williams, G. (2010)."ESL Teaching: How Language and Culture are Interdependent”. Language Study. November 2010.

[23] Wu, J. (2010). A Content Analysis of the Cultural Content in the EFL Textbooks. Canadian Social Science, 6(5), $137-144$.

Amir H. Abdalla is an assistant professor of English and he was born in Khartoum (Sudan) in 1971. He earned his PhD in English from Khartoum University in 2009. His major field of study was English and English language teaching. He taught English 
at several Sudanese universities and English language training centres. He is currently heading the English department of the Community College, Taif University (KSA). He published in the Journal of American Arabic Academy for Sciences and Technology (AMARABAC), the Journal of Language Teaching and Research (JLTR) and the Intuition Journal of Social Sciences and Humanities. Currently, he is conducting research in the field of EFL teaching and learning. 